Alenka Šalej Lah'1, Peter Fajfar'1, Zoran Lavrič², Vili Bukošek³, Tatjana Rijavec ${ }^{3}$

${ }^{1}$ University of Ljubljana, Faculty for Natural Sciences and Engineering, Department for Materials and

Metallurgy, Aškerčeva 12, SI-1000 Ljubljana, Slovenia

2University of Ljubljana, Faculty of Pharmacy, Department of Pharmaceutical Technology,

Aškerčeva cesta 7, SI-1000 Ljubljana, Slovenia

${ }^{3}$ University of Ljubljana, Faculty for Natural Sciences and Engineering, Department of Textiles, Graphic Arts

and Design, Snežniška 5, SI-1000 Ljubljana, Slovenia

\title{
Preparation of Shape Memory NiTiNOL Filaments for Smart Textiles
}

\author{
Original Scientific Article
}

Received 03-2016 • Accepted 04-2016

\begin{abstract}
A nickel-titanium alloy (NiTiNOL, nitinol) filament with a diameter of $200 \mu \mathrm{m}$ was used for preparing a smart knitted textile fabric with a shape memory effect within the range of human body temperatures. The annealing of the filament at $500{ }^{\circ} \mathrm{C}$ for 30 minutes was followed by air cooling at $20^{\circ} \mathrm{C}$ to achieve a suitable transition temperature from martensite to austenite phase within the range between room temperature and $75{ }^{\circ} \mathrm{C}$. The tensile properties of filaments before annealing and after it were analysed on Instron 6022 dynamometer. The measurements of exact transition temperatures from soft martensite state at room temperature to hard austenite state at heating were made on a dynamic mechanical analysis instrument. From the annealed filament a left-right knitted fabric was hand made. The fabric was trained into a selected 3D form by cyclic heating in a strained form at $75^{\circ} \mathrm{C}$ for 10 minutes and then cooled at room temperature. For a stable two-way memory effect, the nitinol fabric needed to make fifteen cycles of heating and cooling. Keywords: smart textiles, shape memory materials, shape memory alloys, nitinol
\end{abstract}

\section{Introduction}

NiTiNOL (nitinol hereafter) is a shape memory nickel-titanium alloy, which can change its shape in a wide temperature range, from $-50{ }^{\circ} \mathrm{C}$ to $+166{ }^{\circ} \mathrm{C}$ [1]. It is one of rare shape memory alloys which with certain chemical composition show a shape memory also within the range of human body temperatures. In comparison to other shape memory materials, like shape memory polymers, nitinol distinguishes itself by better stability of shape memory [2] and super-elastic properties with up to $8 \%$ elastic deformation [3]. Nitinol alloys are the most often used shape memory alloys in the area of smart textile materials, especially in clothes.

The ability to memorize a desired shape is related to nitinol special crystalline structure, to its austenite

Corresponding author:

Alenka Šalej Lah

E-mail: alenka.salej@gmail.com and martensite crystal phases, which under the influence of temperature changes, heating or cooling, or stress changes can reversibly convert from one phase to another [4]. Temperatures at which the conversions happen depend on the chemical composition and the annealing process of nitinol. Transition temperatures are described: by a temperature at which the transformation from martensite to austenite phase starts $\left(A_{s}\right)$, by a temperature at which this transformation is complete $\left(A_{f}\right)$, by a temperature at which the transformation of austenite to martensite phase starts $\left(M_{s}\right)$ and, finally, by a temperature at which this transformation is complete $\left(M_{f}\right)$ (Figure 1a) [4].

Although numerous studies and patents of nitinol alloy for different uses were published in last decades, commercially successful products are today still relatively low, mainly due to the high price of nitinol and

Tekstilec, 2016, 59(2), 168-174

DOl: 10.14502/Tekstilec2016.59.168-174 
the complexity of nitinol alloys processing to achieve desired thermomechanical properties. The use of nitinol is meaningful primarily in the areas where traditional materials do not provide adequate solutions.

Textiles are flexible materials which can easily change shape and can also follow the forms of embedded shape memory fibrous materials. Beside the unique uses of nitinol for kinetic garments by designers $[6,7]$, some interesting functional prototype solutions have been developed, like NiTi micro-hook in Velcro fasteners [8], elastic compression knitting [9], smart curtains [10, 11], where nitinol filaments were integrated into woven or knitted fabric structures and trained into desired temporary forms.

Figure $1 \mathrm{~b}$ showes an example of a shape changes diagram of a fabric with embedded trained nitinol fine filaments. At room temperature (point a2) the fabric is soft and deformable while the nitinol filaments are in a multiple variant of twinned martensite phase. Loading the fabric by stretching, shrinking, bending or folding etc. causes macroscopic wrinkling of the fabric which is accompanied with structural changes in the crystalline structure of nitinol filaments into a single variant of detwinned martensite state (point a3 and a4). After unloading, the fabric preserves the macroscopic form and soft touch. There is no conversion to multiplevariants and only a small elastic strain is recovered, leaving the material with a large residual strain [5]. The structure of nitinol filaments stays in detwinned martensite state (point a5). Heating the fabric up to a certain temperature causes that the fabric changes

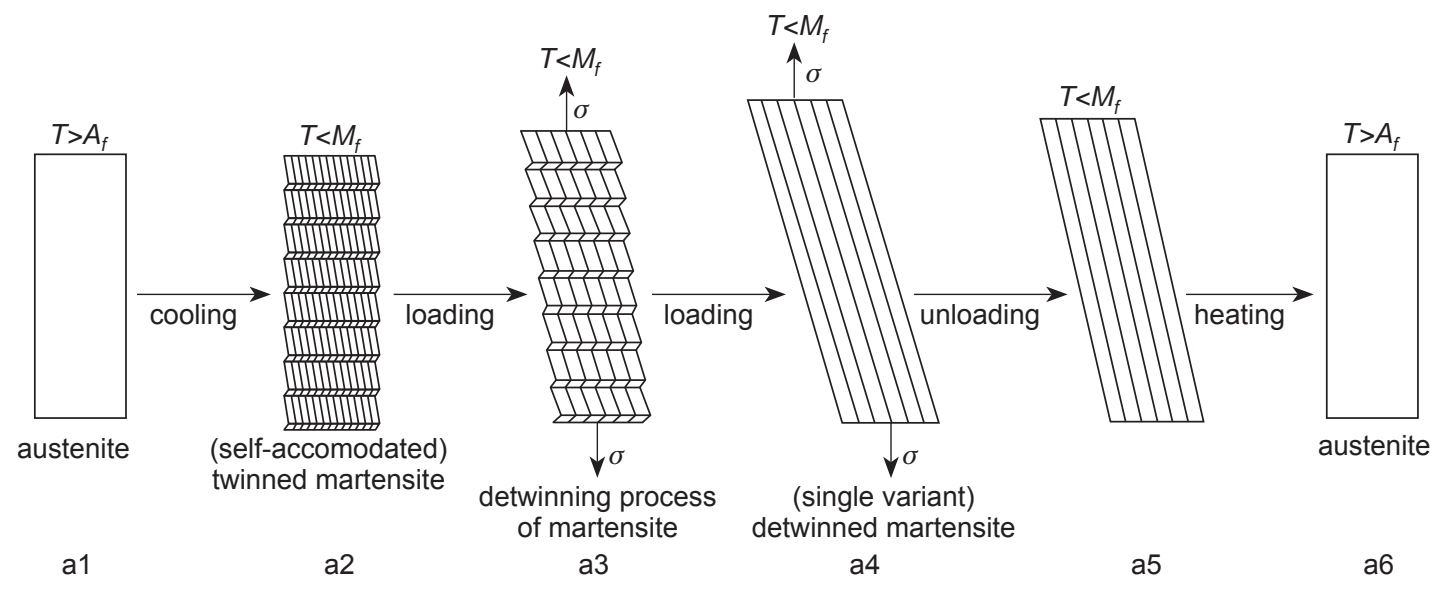

(a)

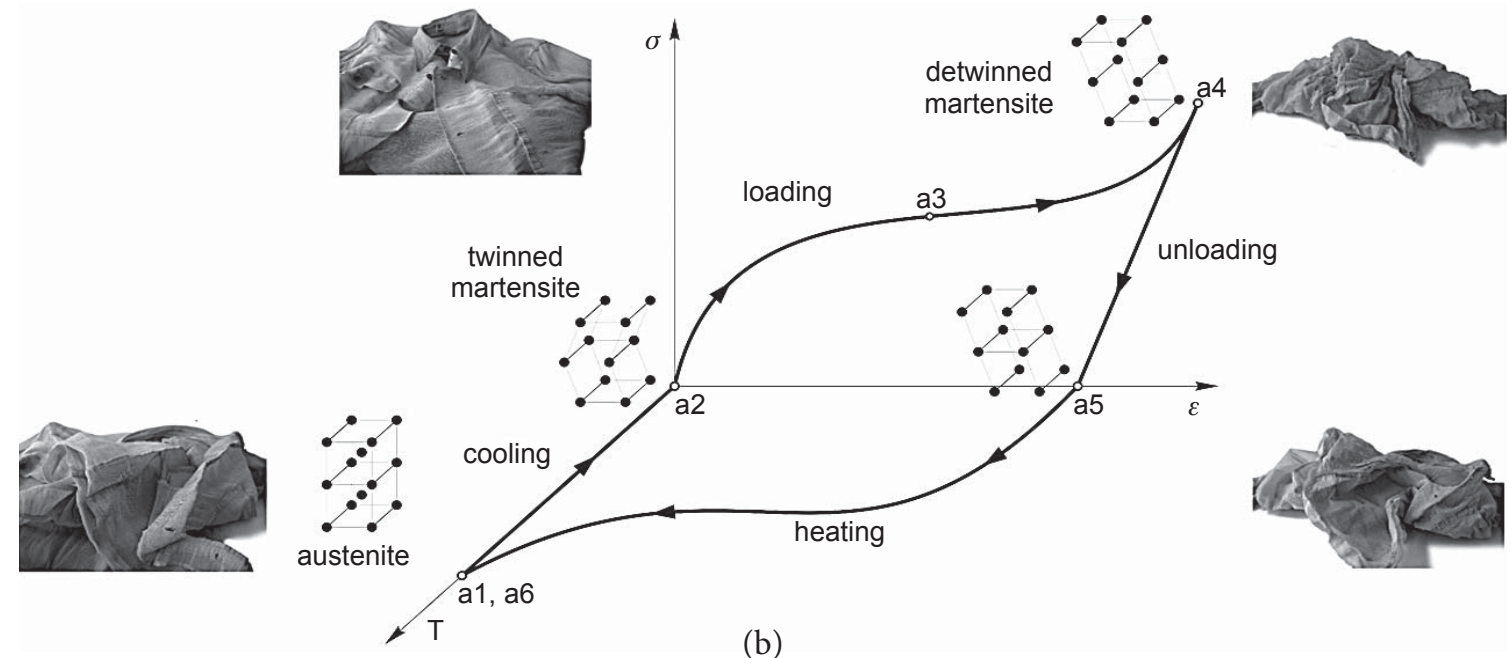

Figure 1: Shape memory effect: (a) diagram of crystal phases transformations of nitinol alloy by temperature and stress [5], (b) an example of shape changing of smart textile fabric with Nitinol filaments as function of stress $(\sigma)$, temperature $(T)$ and deformation $(\varepsilon)$ 
its shape into a preprogramed (unwrinkled) form (point a1/a6), which is followed by the changes into the austenite crystal microstructure. Cooling the fabric to room temperature leads to transition from hard and rigid austenite phase to soft twinned martensite state (point a2).

The area of using nitinol fibres in textiles is nowadays still largely restricted to unique uses. The main problems are the complexity of annealing nitinol filaments to set proper transition temperatures, the training process to set temporary desired shape and the problems connected with the integration of nitinol filaments into fabrics when using existing weaving or knitting machines.

The basic concept of the doctoral research, part of which is presented in this article, is the study of a weft knitted fabric made from $100 \%$ nitinol filaments, which would be inserted as interlining into a garment to create an air gap for increasing thermal insulation properties of such garment. In the article, properties of cold drawn and annealed nitinol filaments are compared beside the presentation of preparing a weft knitted fabric in its permanent and temporary shape memory forms.

\section{Experimental}

In the research, a cold worked nitinol filament with a diameter of $0.2 \mathrm{~mm}$ (Fort Wayne Metals, Ireland) with the characteristics listed in Table 1 was used.

Table 1: Properties of nitinol filament used in the research [12]

\begin{tabular}{|l|c|}
\hline \multicolumn{1}{|c|}{ Properties } & $\begin{array}{c}\text { Nitinol \#6 } \\
\text { alloy }\end{array}$ \\
\hline Thickness [mm] & 0.200 \\
\hline Content of nickel/titanium [\%] & $55.47 / 44.53$ \\
\hline Breaking force [N] & 56.01 \\
\hline Tensile stress* [MPa] & 1772 \\
\hline Breaking elongation* [\%] & 8.2 \\
\hline Yield load [kg] & 4.23 \\
\hline Modulus of elasticity [GPa] & 54.7309 \\
\hline Cold work [\%] & 44.5 \\
\hline$A_{f}\left[{ }^{\circ} \mathrm{C}\right]$ & +40 to +80 \\
\hline
\end{tabular}

* Testing conditions: gage length $254 \mathrm{~mm}$, testing speed $25.4 \mathrm{~mm} / \mathrm{min}$.
The cold worked filament with $A_{f}$ temperature in between $+40^{\circ} \mathrm{C}$ and $+80^{\circ} \mathrm{C}$ was annealed at $400{ }^{\circ} \mathrm{C}$, $450^{\circ} \mathrm{C}$ and $500{ }^{\circ} \mathrm{C}$ for 30 minutes in a furnace.

The transition temperatures of nitinol filaments were measured by differential scanning calorimetry (DSC) on Mettler DSC 1 apparatus (Mettler Toledo, Swizerland) at speed $5{ }^{\circ} \mathrm{C} / \mathrm{min}$ in a temperature range from $-50{ }^{\circ} \mathrm{C}$ to $100^{\circ} \mathrm{C}$. A dynamic mechanical analysis (DMA) of only transition temperatures of nitinol filaments at heating was made on Q-800 apparatus (TA Instruments, USA) at a frequency of $10 \mathrm{~Hz}$ in the temperature range from $0{ }^{\circ} \mathrm{C}$ to $120^{\circ} \mathrm{C}$ with a heating speed $2{ }^{\circ} \mathrm{C} / \mathrm{min}$.

The tensile properties of nitinol filaments were measured on Instron 5567 dynamometer (Instron, GB) at gage length $250 \mathrm{~mm}$ and testing speed $5 \mathrm{~mm} / \mathrm{min}$.

\section{Results and discussion}

The purchased cold worked nitinol filament was characterised by its mechanical properties and a range of austenite temperatures (Table 1). For being used in smart textiles as shape memory material, the worked cold nitinol filaments were firstly annealed to set proper transition temperatures. For NiTi alloy application the transition temperature should be within the range slightly above the temperature of a human body. DSC thermograms showed the transition temperatures $\left(M_{s}, M_{\beta} A_{s}\right.$ and $\left.A_{f}\right)$ of annealed nitinol filaments. The most proper annealing temperature for the intended use of nitinol filaments was at $500{ }^{\circ} \mathrm{C}$, where nitinol filaments existed in a soft pure martensite phase at room temperature and in a stiff pure austenite state at $75^{\circ} \mathrm{C}$ (Figure 3).

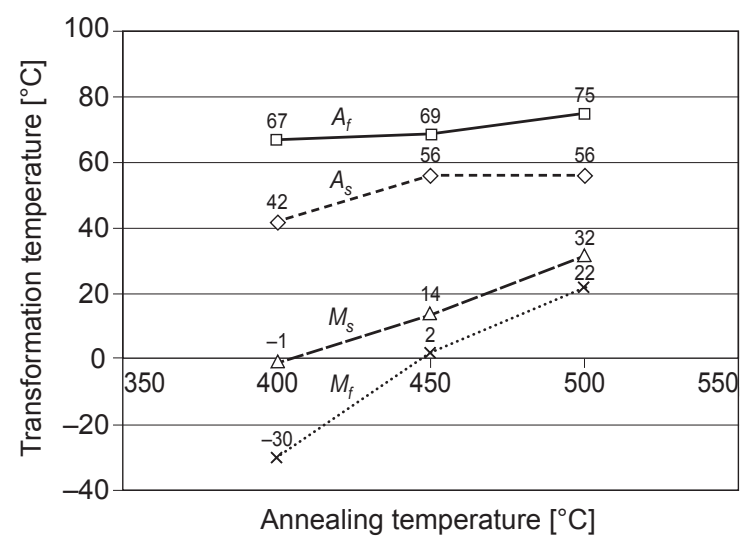

Figure 3: Transition temperatures of nitinol filaments versus annealing temperatures 
The tensile properties of the cold worked and annealed nitinol filaments at $500{ }^{\circ} \mathrm{C}$ were determined at room temperature $\left(20^{\circ} \mathrm{C}\right)$ and at $100{ }^{\circ} \mathrm{C}$ (Figure 4):

- the average measured breaking force of the cold worked nitinol filaments at $20{ }^{\circ} \mathrm{C}$ was $55.2 \mathrm{~N}$ at average breaking elongation 5.1\% (Figure 4a), which is consistent with the declared data given in Table 1;

- the average measured breaking force of the annealed nitinol filaments at $20^{\circ} \mathrm{C}$ was (Figure 4b) $34.0 \mathrm{~N}$ at average breaking elongation $7.6 \%$;

- the breaking force of the cold worked nitinol measured at $100{ }^{\circ} \mathrm{C}$ (Figure 4c) showed a little lower average breaking force of $50.9 \mathrm{~N}$ at average breaking elongation of $4.5 \%$ than at room temperature;

- the average average breaking force of the annealed nitinol filaments at $100{ }^{\circ} \mathrm{C}$ (Figure $4 \mathrm{~d}$ ) was $33.3 \mathrm{~N}$ at average breaking elongation of $12.2 \%$.

From the stress/elongation diagrams of cold worked and annealed nitinol filaments (Figure 5) the

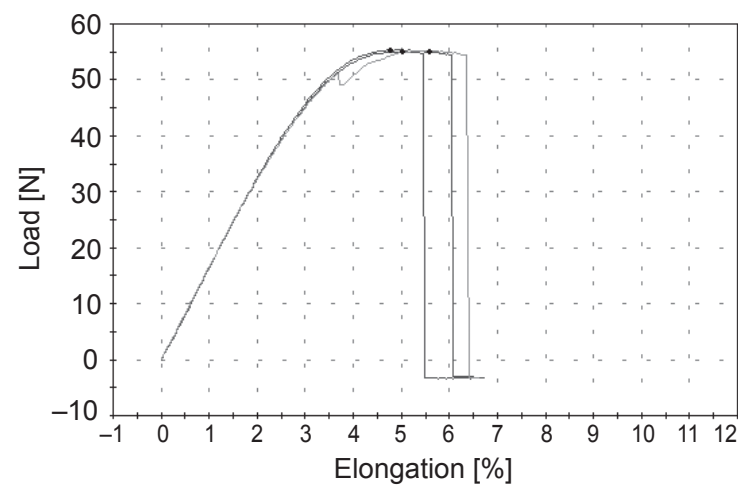

a) cold worked nitinol, measured at $20^{\circ} \mathrm{C}$

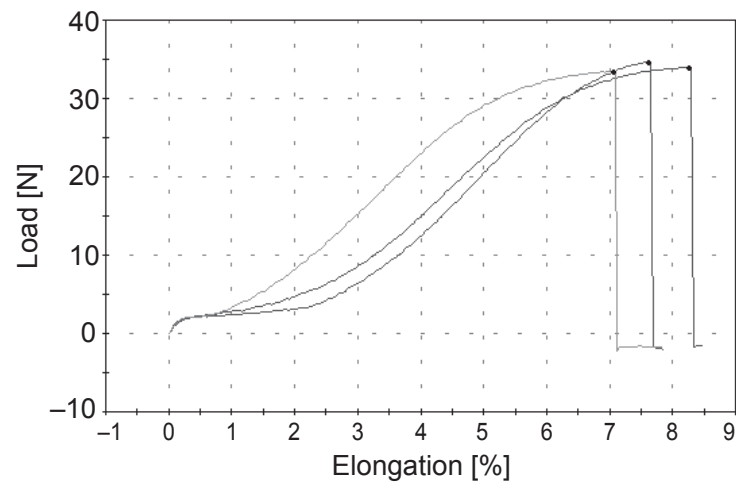

b) annealed nitinol, measured at $20^{\circ} \mathrm{C}$ comparison of their tensile properties in the whole deformation range can be made:

- a cold worked filament shows a similar tensile behavior at $20{ }^{\circ} \mathrm{C}$ and $100{ }^{\circ} \mathrm{C}$ up to $2 \%$ elongation and a little higher tensile stress and elongation within the range between $2 \%$ and breaking elongation at $20^{\circ} \mathrm{C}$ in comparison with $100{ }^{\circ} \mathrm{C}$. Both curves are very steep with distinct elastic behavior. The curves demonstrate a similar microstructure of the cold worked nitinol filament at $20^{\circ} \mathrm{C}$ and at $100{ }^{\circ} \mathrm{C}$;

- the shape of the stress/elongation curves of annealed nitinol filament differs substantially from the shape of the curves of cold worked filaments and is typical for shape memory nitinol alloys. At $20{ }^{\circ} \mathrm{C}$, the annealed material is in martensite state. The curve has a short elastic deformation, and shows no pseudoelasticity. The annealed nitinol filament at $100^{\circ} \mathrm{C}$ is in austenite phase. On the stress/ elongation curve it shows a more pronounced elastic area, and extremely higher modulus of elasticity

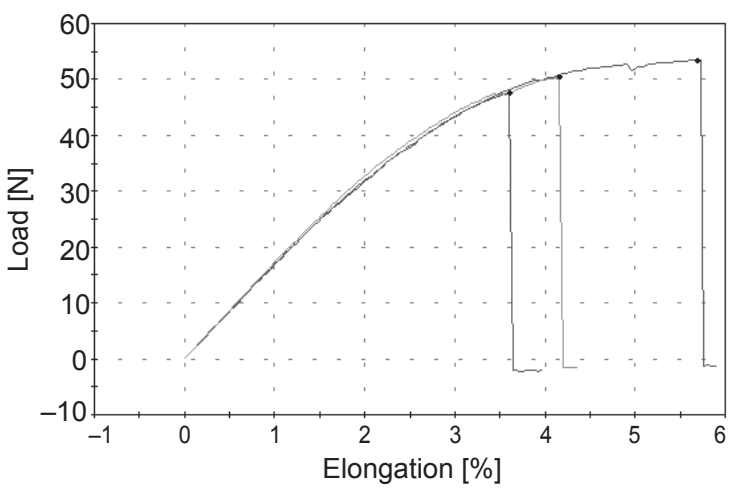

c) cold worked nitinol, measured at $100^{\circ} \mathrm{C}$

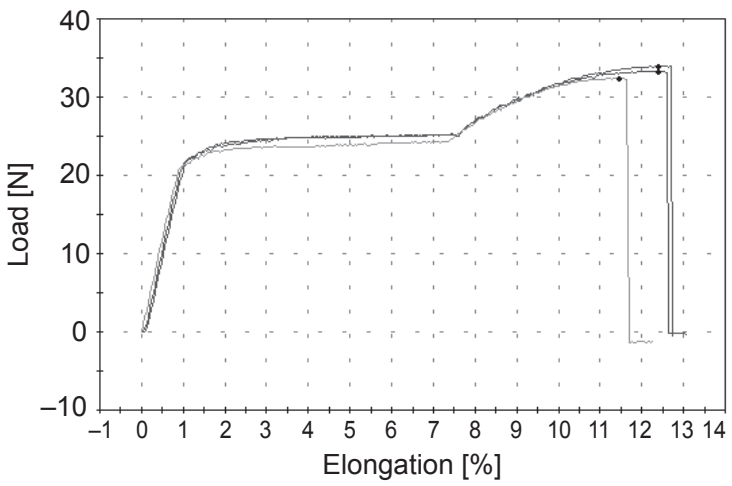

d) annealed nitinol, measured at $100^{\circ} \mathrm{C}$

Figure 4: Tensile load/elongation diagrams of cold-worked $(a, c)$ and annealed $(b, d)$ nitinol filaments, measured at $20^{\circ} \mathrm{C}$ and $100^{\circ} \mathrm{C}$ 
of $60.4 \mathrm{GPa}$ as the annealed filament at $20^{\circ} \mathrm{C}$ that is only $8.95 \mathrm{GPa}$. The breaking stress of the annealed nitinol filament at $100^{\circ} \mathrm{C}$ is $1.06 \mathrm{GPa}$ which is for about $38 \%$ higher than for annealed filament at $20^{\circ} \mathrm{C}$, with the breaking stress of $0.656 \mathrm{GPa}$. The annealed nitinol filament is at $100{ }^{\circ} \mathrm{C}$ in a pseudoplastic state in the elongation range of $1-8 \%$, where the stress-induced austenite to martensite transformation occurs. It is followed by a plastic deformation that leads to the breaking of the filament.

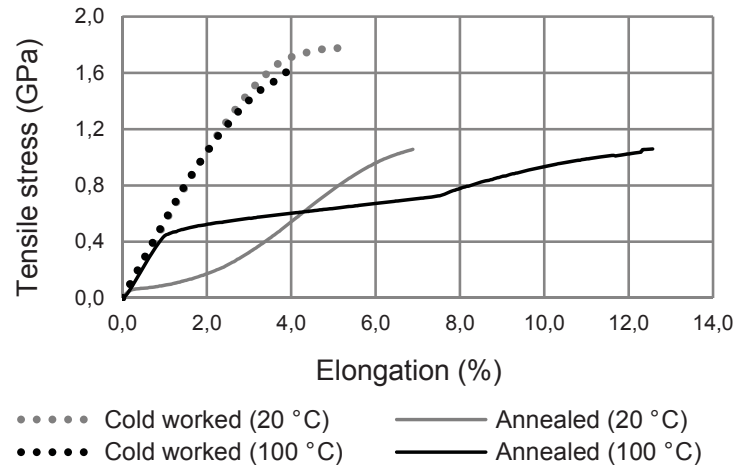

Figure 5: Stress/elongation curves of cold worked and annealed nitinol filaments at $20^{\circ} \mathrm{C}$ and $100{ }^{\circ} \mathrm{C}$

From the results of the DMA measurements the transition temperatures, storage modulus (E'), loss modulus ( $\left.E^{\prime \prime}\right)$ and tangent delta $(\operatorname{tg} \delta)$ depending on the heating temperature and the frequency $(v)$ have been detected (Figure 6):

- storage modulus (E') of the cold worked nitinol filament (Figure 6a) decreases with heating. The value of $28.44 \mathrm{GPa}$ at temperature of $11^{\circ} \mathrm{C}$ monotonously decreases to a value of $26.29 \mathrm{GPa}$ at $98^{\circ} \mathrm{C}$.

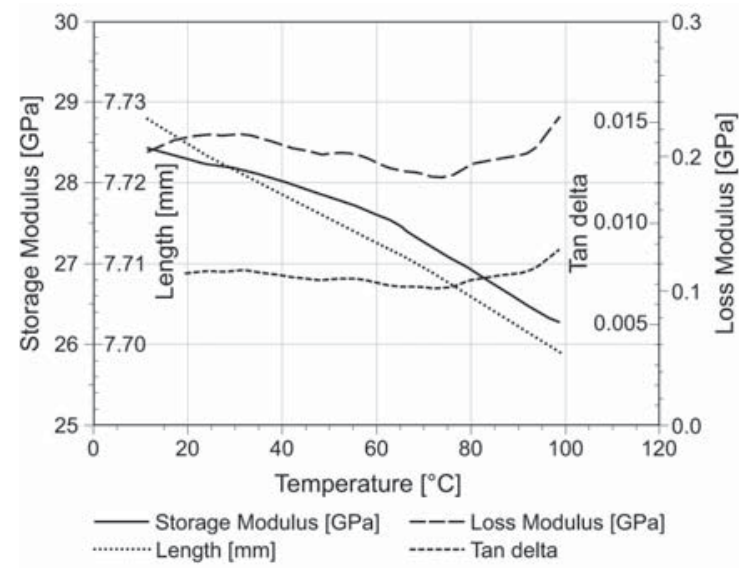

a) cold worked
There is no heat loss in the absence of relaxation passages, that is why the storage modulus (E') remains within the range of $0.2 \mathrm{GPa}(0.213-$ $0.205 \mathrm{GPa})$. Even the tangent delta $(\operatorname{tg} \delta)$ curve, which illustrates the internal movements and damping, shows an extremely small value, about $0.007(0.007-0.009)$, as there is no relaxation oscillations and displacements. On the curve of length changes in dependence of temperature spontaneous flat shrinking of the sample is seen: $-0.029 \mathrm{~mm}$, or $0.38 \%$ to a temperature of $101^{\circ} \mathrm{C}$;

- according to the data of the manufacturer (Table $1)$, the annealed nitinol filament has transformation temperatures from martensite to austenite phase between $40{ }^{\circ} \mathrm{C}$ and $80^{\circ} \mathrm{C}$. This transition is seen on Figure $6 \mathrm{~b}$ between $60^{\circ} \mathrm{C}$ and $80^{\circ} \mathrm{C}$. The value of storage modulus (E') of $30.38 \mathrm{GPa}$ is reducing by applying heat up to the $50{ }^{\circ} \mathrm{C}$ and then continuously increasing due to the transformation of a less regulated monoclinic cell crystal structure of martensite phase in a highly regulated cubic crystal structure of austenite phase. Due to increasing regulation of the crystal structure of austenite, the stress and the storage modulus (E') for the same deformation are higher: up to $100{ }^{\circ} \mathrm{C}$ the storage modulus (E') rises up to $59.87 \mathrm{GPa}$. The maximum transition temperature is at $66.95{ }^{\circ} \mathrm{C}$. Within the temperature range between $60{ }^{\circ} \mathrm{C}$ and $80{ }^{\circ} \mathrm{C}$ the storage modulus increases from $30 \mathrm{GPa}$ to $56 \mathrm{GPa}$;

- loss modulus (E”) also detects the transformation of martensite to austenite phase at temperature of $58.96{ }^{\circ} \mathrm{C}$ : this is the largest heat energy dissipation at the crystal lattice transformation;

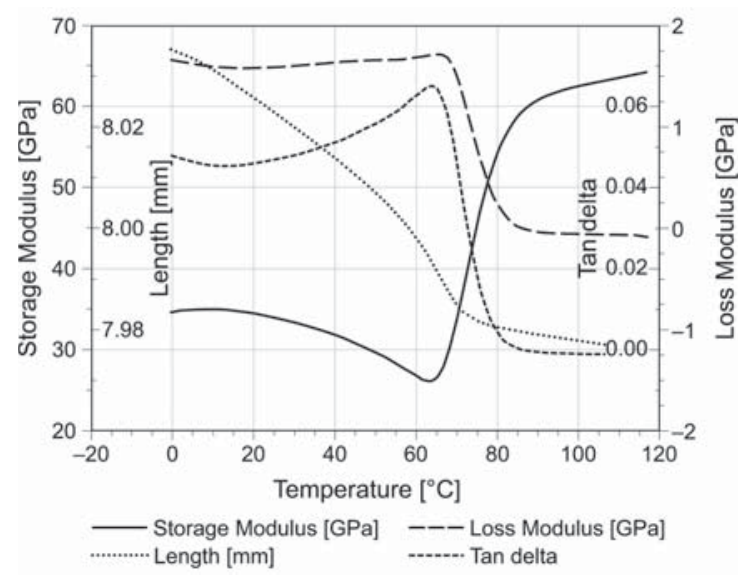

b) annealed

Figure 6: Dynamic mechanical behaviour of cold worked (a) and annealed (b) nitinol filaments 
- tangent delta $(\operatorname{tg} \delta)$ curve detects the mobility of atoms from one crystal lattice to another at the temperature of $56.19^{\circ} \mathrm{C}$. The change in length influenced by the temperature, indicates that the sample is rapidly shrinking up to $70{ }^{\circ} \mathrm{C}$ faster than after the transformation of the austenite structure. Full shrinkage of the sample is -0.03 $\mathrm{mm}$, or $0.29 \%$.

From the cold worked nitinol filament, a hand weft knitted fabric was prepared (Figure 7). For the purpose of annealing and training of the knitted fabric, a special metal prefabricated mould was prepared from a stainless steel and aluminium. Before annealing, the fabric was clamped in a mould framework in a flat state without a pre-stress (Figure 8a). The annealing in a furnace at $500{ }^{\circ} \mathrm{C}$ for 30 minutes was followed by cooling in the air at temperature below $22^{\circ} \mathrm{C}$ for 20 minutes. The annealed fabric was trained to achieve a two-way shape memory. The training process covered heating of annealed fabric at $75^{\circ} \mathrm{C}$ in an oven for 10 minutes with a subsequent cooling in the air below $22^{\circ} \mathrm{C}$ for 20 minutes. After repeating this procedure several times (more than 10-times), the material got a two-way shape memory: it took a temporary form at heating and returned to a permanent form at cooling. The knitted fabric was trained to a temporary three-dimensional half-sphere form (Figure $8 \mathrm{~b}$ ) and into a flat permanent form (8c).

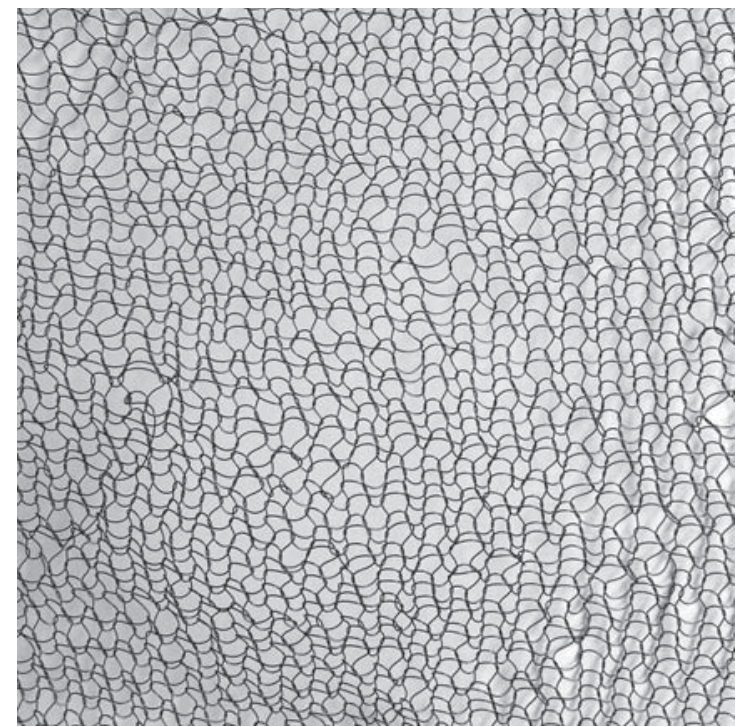

Figure 7: A knitted fabric hand-made from a nitinol filament of a diameter $0.2 \mathrm{~mm}$

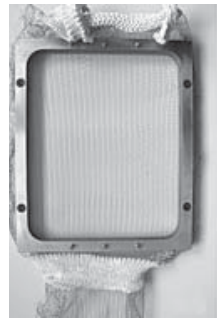

a)

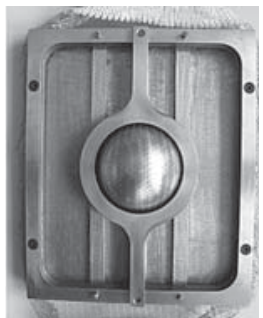

b)

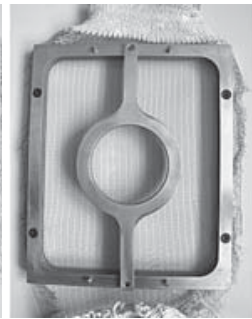

c)
Figure 8: A clamped knitted nitinol fabric: (a) in a mould, prepared for annealing, (b) clamped in a three-dimensional half-sphere form prepared for training with heating, and (c) clamped in mould in a flat form prepared for cooling

\section{Conclusion}

The most important properties of nitinol alloy for integration in textiles and suits are high enough fineness and related flexibility, abrasion and fatigue resistance and rate of shape changing. Due to the high price of shape memory alloys, only unique products and prototypes have been developed until now.

In the study, we successfully trained the nitinol filaments and prepared a functional knitted fabric to be potentially useful as interlining in a personal protecting suit that could dynamically regulate a thickness of air layer to protect a body from high environment heating and feel comfortable in a suit at normal environmental temperatures.

Acknowledgements

This work was financially supported by the Slovenian Research Agency (Grant for the doctoral student A. Šalej Lah).

\section{References}

1. PTIČAR, Matjaž, DOLINŠEK, Slavko, KOSEL, Franc. Prednosti in omejitve pri uporabi materialov $\mathrm{z}$ oblikovnim spominom za praktične uporabne. Strojniški vestnik, 2000, 46(11-12), 780-788.

2. EN/TR 16298 Textiles and textile products Smart textiles - Definitions, categorisation, applications and standardisation needs. Technical report. November 2011, 32 pages. 
3. DALY, Samantha, RITTEL, D. BHATTACHARYA, K. RAVICHANDRAN, G. Large deformation of nitinol under shear dominant loading. experimental mechanics. Experimantal Mechanics, 2009, 49, 225-233.

4. BALAŽIC, Matej, BOMBAČ, David, BROJAN, Miha, CARAM, R., KOPAČ, Janez, KOSEL, Franc. Titanium and titanium alloy applications in medicine. In Surface engineered surgical tools and medical devices. Edited by Mark J. JACKSON and Waqar AHMED. 1st ed. New York; London : Springer, 2007, 533-576, doi: 10.1007/978-0387-27028-9.

5. BROJAN, Miha, BOMBAČ, David, KOSEL, Franc, VIDENIČ, Tomaž. Shape memory alloys in medicine. RMZ- Materials and Geoenvironment, 2008, 55(2), 173-189.

6. CHALAYAN, Hussein. Memory alloy fibers [online], [accessed: 15. 3. 2016]. Available on World Wide Web: $<$ https://www.youtube.com/watch?v= kaCw7rxzJRI $>$.

7. BERZOWSKA, Joanna, COELHO, Marcelo. Kukkia and Vilkas: kinetic electronic garments. Proceedings of the 2005 Ninth IEEE International Symposium on Wearable Computers [online], [accessed: 15. 3. 2016]. Available on World Wide Web: <https://wiki.cc.gatech.edu/ccg/_media/ classes/ muc/flowers.pdf $>$.

8. VOKOUN, David, SEDLÁK, Petr, FROST, Miroslav, PILCH, Jan, MAJTÁS, Dušan, SITTNER,
Petr. Velcro-like fasteners based on NiTi microhook arrays. Smart Materials and Structures, 2011, 20(8), 1-13, doi: 10.1088/0964-1726/20/ $8 / 085027$.

9. Loose and tight. Development of a superelastic material that enables its cost-effective application in highly compliant compression hosiery for the over 18 millions European citizens suffering from chronic venous insufficiency. Co-operative research Project COOP-CT_2005-016868 [online], [accessed: 15. 3. 2016]. Available on World Wide Web: <http://cordis.europa.eu/ docs/publications/1219/121979201-6_en.pdf >.

10. STYLIOS, George K., WAN, Taoyu. Shape memory training for smart fabrics. Transactions of the Institute of Measurement and Control, 2007, 29(3/4), 321-336, doi: 10.1177/ 0142331207069479.

11. DYER, Patric. Dynamic control of active textiles: the integration of nickeltitanium shape memory alloys and the manipulation of woven structures: thesis. Brighton : University of Brighton, 2010 [online], [accessed: 15. 3. 2016]. Available on World Wide Web: <http://eprints.brighton.ac. uk/12268/1/Patrick\%20E.\%20Dyer\%20PhD\% 20Thesis\%202010\%20_Redacted.pdf>.

12. Mechanical properties. Shape memory alloys [online], Fort wayne metals [accessed: 15. 3. 2016]. Available on World Wide Web: <http:// www.fwmetals.com/materials/nitinol/wire/>. 